JIPFRI, Vol. 3 No. 2

Halaman: 129-135

November 2019
JIPFRI (Jurnal Inovasi Pendidikan Fisika dan Riset IImiah)

https://doi.org/10.30599/jipfri.v3i2.476

\title{
Pengembangan Modul Fisika Online Berbasis Web pada Materi Usaha dan Energi
}

\author{
Fitri Ana Sari ${ }^{1}$, Nyoto Suseno ${ }^{2}$, dan Riswanto ${ }^{3^{*}}$ \\ 1,2,3 Universitas Muhammadiyah Metro \\ ‘E-mail: rumbiariswan@gmail.com
}

\begin{abstract}
Abstrak
Sumber daya manusia di sekolah sudah cukup baik dalam memanfaatkan teknologi, informasi, dan komunikasi secara online termasuk dalam bidang pendidikan. Kondisi di lapangan menunjukkan bahwa di beberapa sekolah dalam pembelajarannya sudah berbasis online, namun baru sebatas lingkup blog dan quipper school. Untuk itu perlu dikembangkan modul fisika online berbasis web pada materi usaha dan energi. Penelitian ini merupakan penelitian R \& D (Research and Development) dengan model pengembangan ADDIE (Analysis, Design, Development, Implementation and Evaluation). Hasil penelitian menunjukkan bahwa tingkat kelayakan menurut ahli dan respon siswa yang berada pada kriteria layak dengan persentase masing-masing sebesar $85 \%$ dan $72,5 \%$. Modul fisika online berbasis web dapat digunakan sebagai sumber belajar mandiri. Produk ini, sebaiknya agar dapat dikembangkan untuk materi fisika SMA lainnya
\end{abstract}

Kata kunci: Penelitian dan Pengembangan, Modul Fisika Online, Sumber Belajar

\begin{abstract}
Human resources at school is good enough in utilizing technology, information, and communication online including in the field of education. Conditions on the ground show that in some schools in the learning is based online, but only limited scope blog and quipper school. For that we need to develop web-based online physics module on business material and energy. This research is $R \& D$ (Research and Development) model of ADDIE (Analysis, Design, Development, Implementation and Evaluation). The results showed that the level of feasibility according to the expert and the response of student's who are on the criteria worth with a percentage of $85 \%$ and $72.5 \%$ respectively. The web-based online physics module can be used as a self-learning resource. This product, should be developed for other high school physics materials
\end{abstract}

Keywords: Research and Development, Online Physics Module, Learning Resources

\section{PENDAHULUAN}

Pendidikan memegang peranan penting dalam meciptakan masyarakat yang cerdas baik secara emosional, spiritual, maupun intelektual. Meningkatnya kualitas pendidikan akan berpengaruh positif dalam proses pembangunan di Indonesia. Pemerintah telah berusaha untuk mengembangkan dan menyempurnakan sistem pendidikan di Indonesia demi tercapainya tujuan pendidikan nasional, salah satu cara yang telah dilakukan oleh pemerintah yaitu dengan mengembangkan dan menyempurnakan kurikulum. Perbedaan proses pelaksanaan pembelajaran pada Kurikulum 2013 dengan KTSP.

Hasil pra survei yang dilakukan di SMA Negeri 1 Metro, SMA Negeri 2 Metro, SMA Muhammadiyah 1 Trimurjo dan SMA Negeri 6 Metro. Mendapatkan hasil bahwa pada SMA Muhammadiyah 1 Trimurjo masih menggunakan kurikulum KTSP, sedangkan untuk SMA Negeri 1 Metro, SMA Negeri 2 Metro dan SMA Negeri 6 Metro sudah menggunakan Kurikulum 2013 revisi 2017 untuk kelas X. Dari keempat sekolah tersebut sumber belajar yang digunakan berupa buku cetak dan buku LKS, adapun sekolah yang sudah menggunakan sumber belajar lain yaitu pada SMA Negeri 2 Metro dan SMA Negeri 1 
Metro sudah menggunakan sumber belajar berupa quipper school. Quipper school merupakan sebuah platform online gratis untuk guru dan siswa, quipper school link digunakan oleh guru dalam mengelola kelas secara online dan melihat perkembangan siswa. Sedangkan quipper school learn merupakan tempat belajar siswa, platrorm online merupakan salah satu sumber belajar yang memanfaatkan jaringan internet. SMA Negeri 2 Metro terkadang menggunakan platrorm online dan blog karena fasilitas sekolah yang sudah baik, setiap kelas dan ruangan sudah memiliki jaringan internet masing-masing berupa wifi namun dalam proses pembelajaranpun guru masih juga menggunakan buku cetak maupun LKS. . Menurut guru fisika di SMA Negeri 2 Metro penggunaan quipper school dan blog cakupan materinya kurang luas dan terkadang tidak sesuai dengan silabus, selain itu pada saat siswa belajar menggunakan quipper school siswa harus didampingi oleh guru, mereka tidak dapat belajar mandiri dengan alasan tidak ada petunjuk penggunaannya.

Menurut Association Education Comunication and Tehnology (AECT,1977) dalam (Kasrina, Sri, \& Wahyu E, 2012) yaitu berbagai atau semua sumber baik berupa data, orang, dan wujud tertentu yang dapat digunakan siswa dalam belajar, baik secara terpisah maupun terkombinasi sehingga mempermudah siswa dalam mencapai tujuan belajar. Menurut (Dwito Purnomo, Meti Indrowati, 2013) sumber belajar merupakan bahan-bahan yang dimanfaatan dan diperlukan dalam proses pembelajaran, yang dapat berupa buku teks, media cetak, media elektronik, narasumber, lingkungan sekitar, dan sebagainya yang tersedia di sekitar lingkungan belajar yang berfungsi untuk membantu optimalisasi hasil belajar. Dalam hal ini, sumber belajar merupakan segala macam bahan yang dapat digunakan untuk memberikan infomasi yang terkait dengan materi pembelajaran, sumber belajar dapat berupa buku teks, media cetak, media elektronik, orang, data, lingkungan sekitar, jaringan internet, dan sebagainya. Penggunaan sumber belajar dalam proses pembelajaran peserta didik dapat mempermudah pesera didik didalam mencapai tujuan atau kompetensi pembelajaran.

Menurut (Suseno \& Riswanto, 2017) dan (Nyoto Suseno, 2017) mengemukakan bahwa Inventaris laboratorium online untuk manajemen dan administrasi laboratorium dapat dimanfaatkan dalam menunjang proses pembelajaran fisika secara efektif dan efisien, sehingga memudahkan guru dan siswa dalam kegiatan praktikum. Modul merupakan bahan ajar mandiri (cetak atau perangkat lunak/software) yang disusun secara sistematis dan menarik menurut (Siti Chodijah, Ahmad Fauzi, 2012). Modul online adalah salah satu sumber belajar yang memanfaatkan Teknologi, Informasi dan Komunikasi (TIK). Cakupan materi pada modul online lebih luas dan sesuai dengan silabus, selain itu siswa dapat belajar secara mandiri dengan adanya petunjuk penggunaan modul tanpa harus didampingi oleh guru. peningkatan aktivitas tersebut akan mampu membentuk karakter siswa secara kontinu menurut (Riswanto \& Dewi, 2017).

Berdasarkan uraian di atas, maka tujuan penelitian ini adalah untuk menghasilkan modul fisika online berbasis web yang layak agar mampu membantu siswa belajar secara mandiri. Modul yang ada saat ini didominasi oleh modul cetak yang memiliki Kelemahan yaitu tidak praktis. Hasil penelitian (Aji, Hudha, \& Rismawati, 2017) menunjukan bahwa pengembangan kelayakan modul yang berbasis pada problem based learning (PBL) hanya dilihat pada aspek isi dan penyajian, belum menilai pada ukuran kepraktisan penggunaan modul. Selain itu, hasil penelitian (Rahmawati, Astra, \& Susanti, 2012) menunjukan hasil bahwa siswa memiliki ketertarikan menggunakan modul elektronik fisika yang dilengkapi dengan tes sumatif maupun formatif. Berdasarkan kajian hasil penelitian terdahulu, maka penelitian ini difokuskan untuk mengukur kepraktisan modul online yang dikembangkan.

\section{METODE/EKSPERIMEN}

Penelitian ini merupakan penelitian pengembangan (Research and Development). Menurut Sugiyono (2011:407) metode penelitian dan pengembangan atau dalam 
bahasa inggrisnya Research and Development adalah metode penelitian yang digunakan untuk menghasilkan produk tertentu, dan menguji keefektifan produk tersebut.

Model yang digunakan dalam pengembangan modul fisika online ini adalah model pengembangan ADDIE. Mulyatiningsih, 2011) menyatakan bahwa ADDIE merupakan singkatan dari Analysis (Analisis), Design (desain), Development or Production (Produksi), Implementation or Delivery (Produksi), and Evaluations (Evaluasi).

Untuk mengetahui tingkat keberhasilan pada penelitian pengembangan ini, digunakan angket. Angket digunakan untuk mengukur kelayakan dari modul fisika online berbasis web berdasarkan dari sisi desain media, materi dan respon siswa. Angket diberikan kepada validator yang terdiri dari 2 guru sekolah dan 1 dosen. Sedangkan untuk respon diberikan kepada siswa. Angket yang dibuat menggunakan format respon skala Likert, dengan bobot respon setiap skalanya adalah Sangat Baik bobot (4), Baik bobotnya (3), Cukup Baik bobotnya (2), dan Tidak Baik bobotnya (1). Penilaian yang dilakukan mencakup tiga hal diantaranya yaitu penilaian kelayakan isi, penilaian kelayakan penyajian dan penilaian kelayakan kebahasaan.

\section{HASIL DAN PEMBAHASAN}

\section{HASIL}

Hasil yang diperoleh dari penelitian ini terdiri dari proses analisis kebutuhan, perancangan dan pembuatan modul fisika online berbasis web,validasi pengembangan produk dari sisi desain media dan materi serta ujicoba produk kepada siswa kelas X. Secara ringkas data hasil penelitian dan pengembangan modul fisika online berbasis web adalah sebagai berikut:

\section{- Analisis kebutuhan dan analisis silabus} kurikulum 2013 pada materi Usaha dan Energi

Dari analisis kebutuhan diperoleh hasil yaitu sumber belajar yang digunakan masih berupa buku cetak dan buku LKS, adapula sekolah yang sudah menggunakan quipper school dan blog. Namun, cakupan materi pada quipper school dan blog kurang luas, materi yang disajikan tidak sesuai silabus, dan tidak terdapat petunjuk penggunaannya sehingga siswa tidak dapat belajar secara mandiri.

Analisis silabus kurikulum 2013 yaitu analisis kompetensi inti dan kompetensi dasar. Sehingga memilih materi pelajaran sesuai dengan kurikulum pada tingkat Sekolah Menengah Atas (SMA). Berdasarkan hasil analisis pertimbangan karakteristik materi, maka dipilih materi usaha dan energi yang dikembangkan menjadi materi pada modul online.

\section{- Rancangan awal modul fisika online berbasis web}

Setelah topik usaha dan energi dipilih untuk disusun dalam bentuk modul fisika online, maka tahap selanjutnya adalah perancangan awal dan pengembangan dari modul fisika online. Menurut (Riswanto, 2018) menerangkan bahwa Tampilan informasi materi pelajaran dilihat melalui indera penglihatan, guru akan lebih mudah menyampaikan informasi pelajaran melalui penggunaan media atau peraga yang bersifat visual dan audio.

Desain atau perancangan awal dihasilkan modul fisika online berbasis web memuat sembilan menu tampilan diantaranya yaitu seperti ditunjukan Gambar 1 merupakan menu utama yang mencakup $\mathrm{KI} / \mathrm{KD}$, Materi pembelajaran, evaluasi, ulangan harian, rangkuman dan daftar pustaka rujukan. .

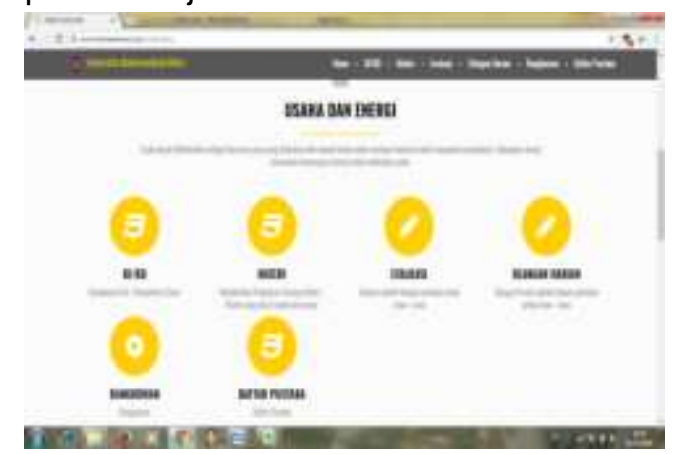

Gambar 1. Tampilan menu utama (home)

Tampilan KI/KD seperti tampak pada Gambar 2 diperlukan untuk menunjukan informasi KI/KD yang pembelajaran. 


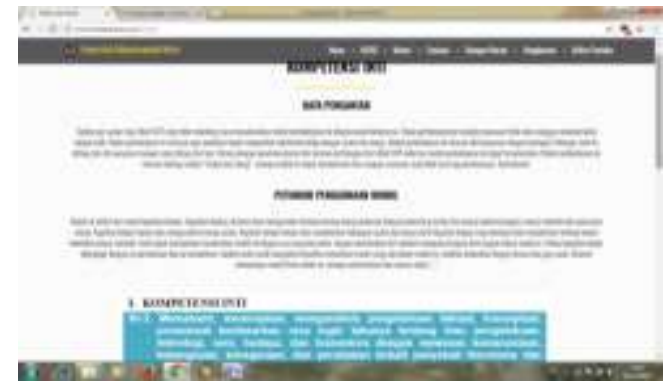

Gambar 2.Tampilan $\mathrm{KI} / \mathrm{KD}$

Tampilan Gambar 3 menunjukan informasi materi yang disajikan berdasarkan pada $\mathrm{KI} / \mathrm{KD}$ diantaranya yaitu materi energy, usaha, hubungan energi dan usaha, hukum kekekalan energi mekanik, dan rangkuman materi.

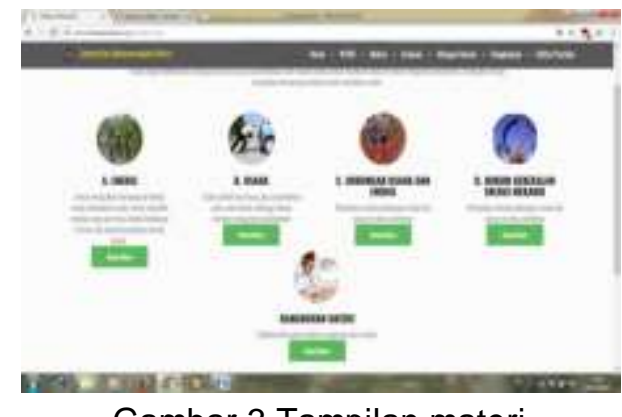

Gambar 3.Tampilan materi

Evaluasi dalam rangka mengukur pencapaian tujuan pembelajaran disajikan dalam bentuk soal online seperti ditunjukkan pada Gambar 4. Evaluasi dengan sistem online diharapkan dapat menjadi sarana latihan bagi siswa, untuk nantinya menghadapi sistem ujian berbasis CAT. Soal evaluasi ini juga membantu siswa untuk mengukur kemampuannya secara mandiri, karena setelah siswa menyelesaikan soal akan muncul hasil skor dari jawaban yang diberikan.

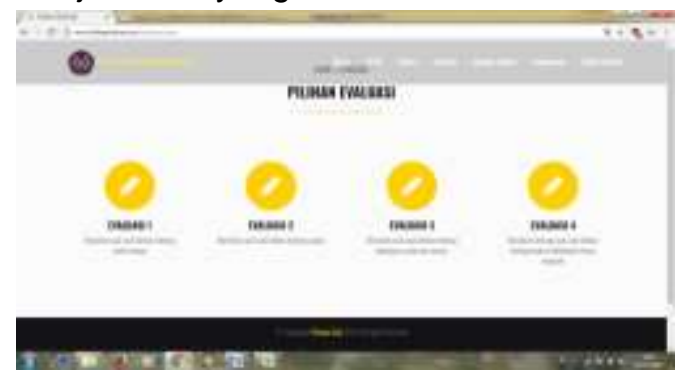

Gambar 4.Tampilan evaluasi

Selain melalui evaluasi mandiri, pengembangan modul online juga dilakukan dengan memberikan ulangan harian secara online yang dilengkapi dengan waktu penyelesaian soal seperti tampak pada

\section{Gambar 5.}

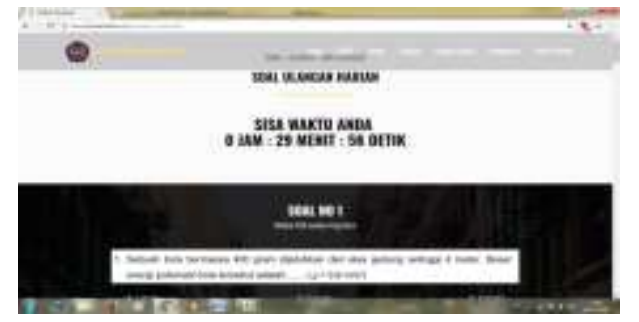

Gambar 5. Tampilan ulangan harian

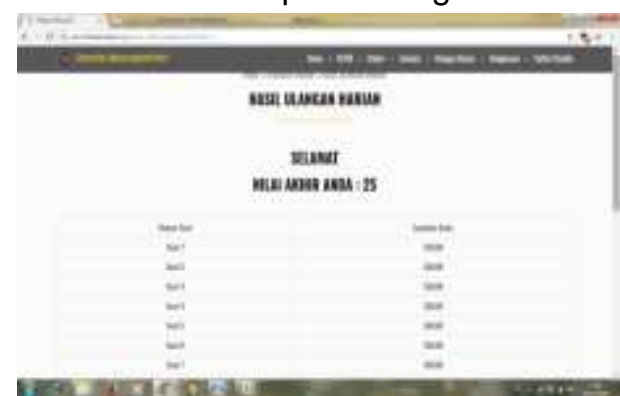

Gambar 6. Tampilan hasil ulangan harian Sementara itu, hasil analisis penyelesaian ulangan harian per butir soal juga akan tampak seperti pada Gambar 6, ini dapat membantu guru dalam mengevaluasi kualitas soal yang diberikan kepada para siswanya.

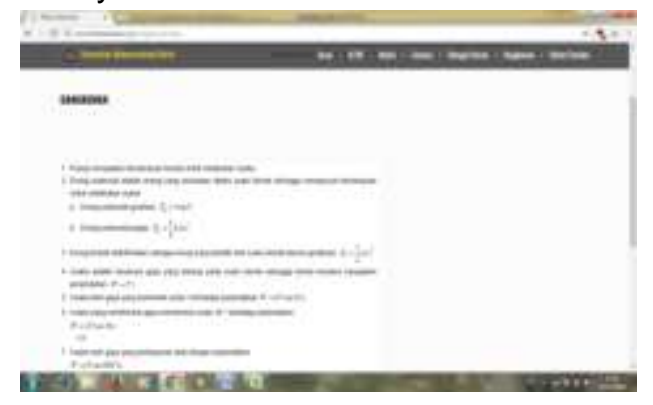

Gambar 7. Tampilan rangkuman

Modul online juga menyajikan fitur rangkuman seperti tampak pada Gambar 7 . Fitur ini berguna untuk membantu para siswa mengingat kata kunci persamaan dan materi pembelajaran.

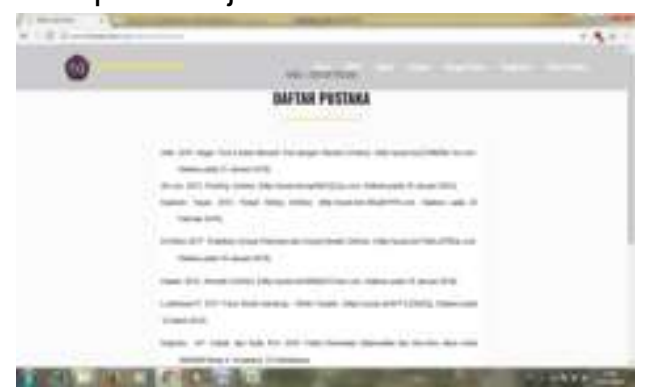

Gambar 8. Tampilan daftar pustaka

Tampilan daftar pustaka seperti tampak pada Gambar 8 disajikan sebagai sarana bagi siswa untuk mendalami dan 
memperkaya informasi materi dengan membaca referensi/rujukan modul.

Tahap selanjutnya adalah implementasi berupa pengujian kelayakan ahli desain media dan materi serta uji coba kelompok kecil/ uji coba lapangan oleh siswa.

\section{Uji Kelayakan Ahli Desain Media}

Uji ini melibatkan dosen Universitas Muhammadiyah Metro dan guru fisika SMA N 2 Metro. Dari hasil angket validasi ahli desain media, didapatkan persentase rata-rata skor angket yang disajikan dalam bentuk grafik pada Gambar 9.

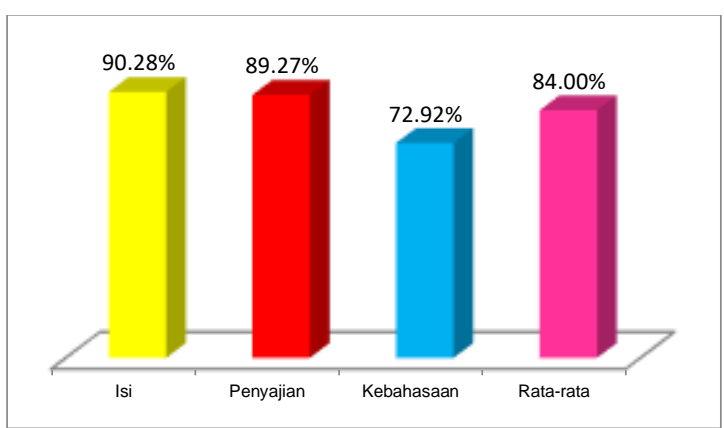

Gambar 9. Grafik persentase rata-rata tiap komponen

\section{Uji Kelayakan Ahli Materi}

Uji ini melibatkan dosen Universitas Muhammadiyah Metro dan guru fisika SMA N 2 Metro. Dari hasil angket validasi ahli materi, didapatkan persentase rata-rata skor angket yang disajikan dalam bentuk grafik pada Gambar 10.

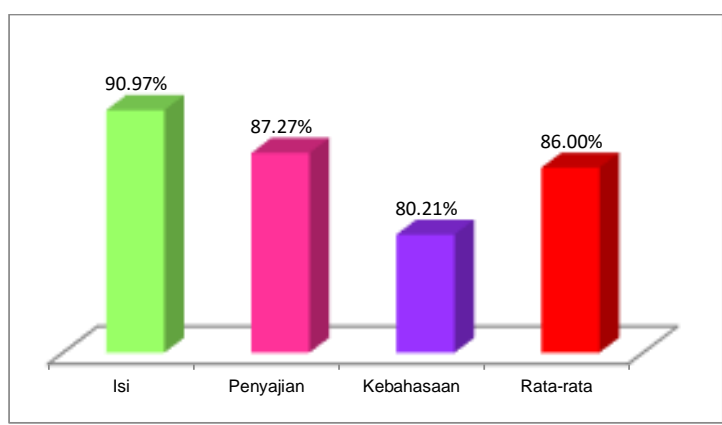

Gambar 10. Grafik persentase rata-rata tiap komponen

\section{Uji Coba Kelompok Kecil/ Uji Coba Lapangan oleh Siswa \\ Uji coba kelompok keci/ uji coba}

lapangan dilakukan oleh siswa SMA dengan melibatkan 30 orang siswa kelas X IPS ${ }_{3}$ dan 26 orang siswa kelas $X \mathrm{IPS}_{4}$ SMA N 2 Metro dengan menggunakan angket respon siswa. Dari hasil angket respon siswa, didapatkan persentase rata-rata skor angket yang disajikan dalam bentuk grafik Gambar 11 .

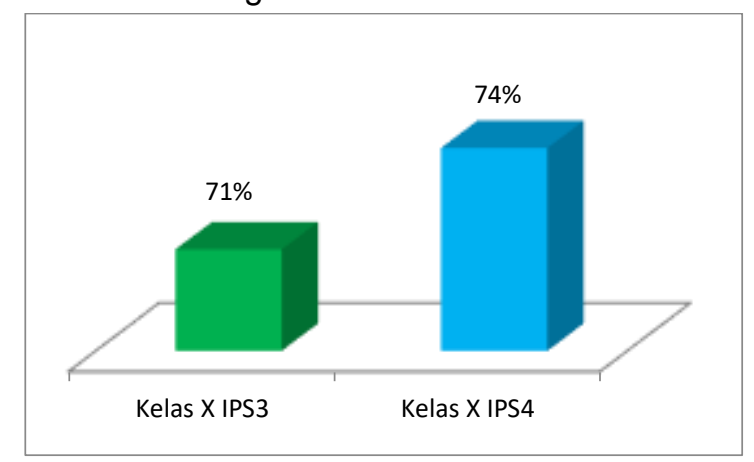

Gambar 11. Grafik respon siswa terhadap modul fisika online

\section{PEMBAHASAN}

Berdasarkan dengan hasil uji kelayakan ahli media, ahli materi dan respon siswa maka dapat diketahui bahwa persentase rata-rata seluruh komponen desain media termasuk ke dalam kriteria sangat layak dengan persentase $84 \%$, dapat dilihat dari kelengkapan isi modul yang meliputi teks, gambar, simbol, video dan animasi sudah lengkap. Penggunaan gambar dan animasi tambahan tidak mengganggu pembaca dan penyajian keseluruhan ilustrasi sudah sangat serasi. Persentase rata-rata seluruh komponen materi termasuk ke dalam kriteria sangat layak dengan persentase $86 \%$, dapat dilihat dari kesesuaian isi materi, penyajian dan kebahasaan dari aspek materi sudah sangat sesuai dengan tingkat perkembangan berpikir kritis, sosial, emosional dari aspek perkembangan siswa SMA serta sudah sesuai dengan silabus kurikulum 2013 revisi 2017. Menurut (Rahmawati et al., 2012) modul fisika online berbasis web dapat digunakan sebagai media pembelajaran fisika secara mandiri apabila kualitas media menurut ahli media baik, dari aspek daya tarik dan isi modul. Kualitas media menurut ahli materi baik, dari aspek kelayakan isi, kebahasaan dan penyajian. Modul online yang dikembangkan berkualitas karena memenuhi kriteria yang teruji oleh ahli 
materi dan ahli media.

Persentase respon siswa dari kedua kelas termasuk kedalam kritreria baik dengan persentase $72,5 \%$, respon siswa terhadap modul fisika online dinilai baik sebagai sumber belajar untuk membantu siswa agar dapat belajar secara mandiri. Sedangkan kesesuaian informasi, usabilitas (kemudahan dalam penggunaan) dan motivasi (efek setelah menggunakan modul fisika online telah sesuai dengan tingkat perkembangan siswa SMA. Menurut (Nurmayanti, Bakri, \& Budi, 2015) kelebihan modul elektronik dengan modul cetak adalah sifatnya yang interaktif memudahkan dalam navigasi, memungkinkan untuk menampilkan/memuat gambar, audio, video dan animasi serta dilengkapi dengan tes/kuis formatif yang memungkinkan umpan balik otomatif dengan segera. Sehingga jika dikaitkan dengan penelitian peneliti bahwa modul fisika online yang dikembangkan memiliki kualitas yang baik digunakan sebagai sumber belajar secara mandiri bagi siswa dengan memanfaatkan teknologi, informasi, dan komunikasi yang telah teruji oleh ahli desain media, ahli materi dan respon siswa melalui penilaian angket validasi dan angket respon siswa.

Modul fisika online yang dikembangkan memiliki keunggulan dan kelemahan sebagai berikut:

1. Keunggulan

a. Tampilan modul fisika online berbasis web memotivasi belajar bagi siswa.

b. Isi materi dan teknik penyajian materi dalam modul fisika online sudah sesuai kurikulum 2013 revisi.

c. Modul fisika online berbasis web cara mengaksesnya cukup mudah dapat diakses dengan kamputer maupun handphone dan waktu mengaksesnya tidak lama tergantung pada jaringan internet yang tersedia.

d. Modul fisika online berbasis web didalamnya terdapat ulangan harian diakhir bab. Ulangan harian berupa soal pilihan ganda dengan waktu pengerjaan soal langsung dapat dilihat oleh siswa setelah siswa melakukan input data dan setelah mengerjakan soal ulangan harian siswa dapat langsung melihat nilai ulangan harian serta mengunduh pembahasaan ulangan harian.

\section{Kelemahan}

a. Materi dan contoh soal yang disajikan dalam modul fisika online terbatas, karena kesulitan dalam pembuatan soal yang sesuai dengan kompetensi.

b. Keterbatasan penulisan pada format penulisan dan penggunaan ilustrasi.

c. Video ilustrasi tidak bisa menampilkan video dengan bentuk link youtube yang ditempel pada halaman web.

\section{PENUTUP}

Berdasarkan hasil pengujian yang telah dilakukan produk hasil pengembangan mendapatkan tingkat kelayakan desain media $84 \%$ dengan subkomponen tertinggi layout design memperoleh persentase rata-rata $89,58 \%$ dan sub komponen yang memperoleh persentase rata-rata terlemah yakni pada sub komponen kejelasan ilustrasi memperoleh persentase $70,83 \%$. Sub komponen tingkat kelayakan materi memperoleh persentase ratarata $86 \%$, tingkat kelayakan tertinggi pada sub komponen ketaatan pada hukum dan perundang-undangan memperoleh persentase $100 \%$ dan sub komponen terendah kesesuaian bahasa dengan ejaan yang benar dan sub komponen komunikasi memperoleh persentase $75,00 \%$. Persentase rata-rata respon siswa memperoleh $72,50 \%$ dengan sub komponen tertinggi motivasi (efek penggunaan modul fisika online) memperoleh persentase rata-rata $75,32 \%$ dan sub komponen terendah pada sub komponen penyajian memperoleh persentase rata-rata $68,14 \%$. Berdasarkan dengan persentase tersebut modul fisika online terletak pada kriteria layak digunakan sebagai sumber belajar yang membantu siswa agar dapat belajar secara mandiri. Modul fisika online dikatakan layak karena telah memenuhi enam aspek kriteria yakni aspek daya tarik, aspek isi modul, aspek isi materi, kebahasaan dan penyajian.

\section{Saran Pemanfaatan Produk}

a. Sebaiknya modul fisika online diperbaiki agar materi yang disajikan lebih dari satu materi/bab. 
b. Disarankan menggunakan bahasa pemrograman link youtube agar video dapat ditempel pada halaman web.

\section{Saran Desiminasi/Penyebaran Produk}

Agar modul fisika online dapat digunakan pada skala luas dan tidak hanya pada sekolah yang menjadi tempat penelitian, maka produk harus diuji cobakan kepada sampel yang lebih banyak.

\section{Saran Penelitian Lanjutan Produk}

a. Untuk peneliti lanjutan sebaiknya produk dibuat tidak hanya pada materi usaha dan energi saja, tetapi untuk banyak materi fisika lainnya. Sehingga dengan adanya sumber belajar berupa modul fisika online dapat membuat siswa lebih termotivasi untuk belajar fisika secara mandiri dengan memanfaatkan perkembangan teknologi dan komunikasi.

b. Dari segi teknis modul fisika online agar dapat memunculkan ide-ide baru untuk memperbaiki kekurangan yang ada pada produk saat ini.

\section{DAFTAR PUSTAKA}

Aji, S., Hudha, M. N., \& Rismawati, A. (2017). Pengembangan Modul Pembelajaran Fisika Berbasis Problem Based Learning untuk Meningkatkan Kemampuan Pemecahan Masalah Fisika. SEJ (Science Education Journal), 1(1), 36. https://doi.org/10.21070/sej.v1i1.830

Dwito Purnomo, Meti Indrowati, P. K. (2013). Pengaruh Penggunaan Modul Hasil Penelitian Pencemaran Di Sungai Pepe Surakarta Sebagai Sumber Belajar Biologi Pokok Bahasan Pencemaran Lingkungan Terhadap Hasil Belajar Siswa. Pendidikan Biologi, 5(1), 59-69. Retrieved from https://jurnal.fkip.uns.ac.id/index.php/bio/ article/view/1439

Kasrina, K., Sri, I., \& Wahyu E, J. (2012). Ragam Jenis Mikroalga Di Air Rawa Kelurahan Bentiring Permai Kota Bengkulu Sebagai Alternatif Sumber Belajar Biologi Sma. Exacta, 10(1), 3644.

Mulyatiningsih, E. 2011. Metode Penelitian Penerapan Bidang Pendidikan. Yogyakarta: Alfabeta.
Nurmayanti, F., Bakri, F., \& Budi, E. (2015). Pengembangan Modul Elektronik Fisika dengan Strategi PDEODE pada Pokok Bahasan Teori Kinetik Gas untuk Siswa Kelas XI SMA. Prosiding Simposium Nasional Inovasi Dan Pembelajaran Sains, 2015(Snips), 337.

Nyoto Suseno, R. (2017). Sistem Pengelolaan Laboratorium Fisika Untuk Mewujudkan Pelaksanaan Praktikum Yang Efisien. JPF Jurnal Pendidikan Fisika, 5(1), 7686.

Rahmawati, Astra, I. M., \& Susanti, D. (2012). Seminar Nasional Fisika 2012 Pengembangan Modul Fisika Online Berbasis Web Pada Pokok Bahasan Kinematika Gerak Lurus ( Physics Of Online Web-Based Modules Kinematics On The Subject Straight Motion ) Seminar Nasional Fisika 2012. Seminar Nasional Fisika 2012.

Riswanto, R. (2018). Pelatihan Pembuatan Alat Peraga Fisika Virtual Bagi Guru-Guru Muhammadiyah Kota Metro. Sakai Sambayan Jurnal Pengabdian Kepada Masyarakat, $\quad 2(3), \quad 102$. https://doi.org/10.23960/jss.v2i3.117

Riswanto, R., \& Dewi, N. A. K. (2017). Peningkatan Keterampilan Proses Sains Melalui Pembelajaran Berbasis Laboratorium Untuk Mewujudkan pembelajaran Berkarakter. Jurnal Riset Dan Kajian Pendidikan Fisika, 4(2), 60. https://doi.org/10.12928/jkpf.v4i2.8164

Siti Chodijah, Ahmad Fauzi, R. W. (2012). Pengembangan Perangkat Pembelajaran Fisika Menggunakan Model Guided Inquiry yang dilengkapi Penilaian Portofolio Pada Materi Gerak Melingkar. Jurnal Penelitian Pembelajaran Fisika, 1(1), 1-19. Retrieved from http://ejournal.unp.ac.id/index.php/jppf/art icle/view/603

Sugiyono. 2011. Metode Penelitian Pendidikan Pendekatan Kuantitatif, Kualitatif, dan R \& $D$. Bandung: Alfabeta

Suseno, N., \& Riswanto, R. (2017). Program Optimalisasi Peran Laboratorium Fisika SMA di Kota Metro, Lampung. Jurnal Pengabdian Pada Masyarakat, 2(2), 149158.

https://doi.org/10.30653/002.201722.28 